\title{
Past Environmental Proxies from the Middle Stone Age at Sibudu, Kwazulu-Natal, South Africa
}

\author{
Grant Hall, Lyn Wadley \& Stephan Woodborne
}

\begin{abstract}
Middle Stone Age technological and behavioural developments in southern Africa are central to understanding the emergence of modern humans, and elucidating the role of environmental change in this trajectory is dependent on emerging palaeoclimatic reconstructions. Climate proxies from Middle Stone Age sites are often poorly preserved, coarsely resolved or subject to anthropogenic selection and are not considered in favour of global environmental proxies despite the fact that the modern climate regimes at the relevant archaeological sites differ profoundly. Sibudu has a well-preserved Middle Stone Age sequence that has yielded abundant palaeoclimate proxy data. Isotopic analysis of charcoal, charcoal anatomy and species representation, macro- and micro-faunal remains, sediment texture, mineralogy and magnetic susceptibility, pollen and macrobotanical remains provide evidence for the environmental succession specific to this site. The isotopic data suggest that archaeological charcoal was not significantly post-depositionally altered. During the Howiesons Poort (65-62 ka) the local environment was thickly forested, moist and more humid than during the $58 \mathrm{ka}$ occupations. The environment changes during the post-Howiesons Poort occupation ( $\sim 58 \mathrm{ka})$ into the late MSA occupation ( $48 \mathrm{ka})$; conditions became drier and colder than present with vegetation shifting to open savanna grassland or woodlands.
\end{abstract}

\section{Résumé}

Les évolutions technologiques et comportementales du Middle Stone Age dans le sud de l'Afrique sont essentielles pour comprendre l'émergence de l'Homme moderne, et la compréhension du rôle des changements environnementaux dans cette trajectoire dépend des reconstitutions paléo-climatiques émergentes. Les données indirectes liées au climat du MSA sont souvent mal conservées, de résolution grossière ou soumis à une sélection d'origine anthropique et sont abandonnées au profit des données indirectes liées aux conditions environnementales globales, en dépit du fait que les régimes climatiques modernes sur les sites archéologiques étudiés diffèrent profondément. Sibudu a une séquence bien conservée du Middle Stone Age qui a fournit d'abondantes données paléoclimatiques indirectes. L'analyse isotopique de charbons de bois, l'anatomie du charbon de bois et la représentation des espèces, des restes de faunes macroscopiques et microscopiques, la texture des sédiments, la minéralogie et la susceptibilité magnétique, le pollen et les restes macrobotaniques fournissent des indices de l'évolution de l'environnement spécifique à ce site. Au cours de la période Howiesons Poort (65-62 ka), l'environnement local est couvert de forêts épaisses et humide, plus humide encore lors des occupations de $58 \mathrm{ka}$. L'environnement change au cours de l'occupation post-Howiesons Poort ( $58 \mathrm{ka}$ ) jusqu'a la fin de l'occupation MSA ( $48 \mathrm{ka})$ : il devient plus sec et plus froid qu'à présent et la végétation se mue en grande savane herbeuse ou boisée.

Keywords: Sibudu, Middle Stone Age, Howiesons Poort, stable carbon isotopes, charcoal, environmental proxies

\section{Grant Hall_Grant.Hall@up.ac.za}

Mammal Research Institute, Faculty of Natural and Agricultural Sciences, University of Pretoria, Private Bag X20, Hatfield 0028, Pretoria, South Africa

Lyn WadleyＬyn.Wadley@wits.ac.za School of Geography, Archaeology and Environmental Studies and the Evolutionary Studies Institute, University of the Witwatersrand, Private Bag 3, Wits 2050, South Africa

Stephan Woodborne Swoodborne@tlabs.ac.za iThemba Laboratories, Private Bag 11, Wits 2050, South Africa

and Mammal Research Institute, Faculty of Natural and Agricultural Sciences, University of Pretoria, Private Bag X20, Hatfield 0028, Pretoria, South Africa 


\section{Introduction}

Archaeological evidence from Blombos Cave, Pinnacle Point and Sibudu archaeological sites reflects the emergence of complex human behaviour in southern Africa over the last 160,000 years (HENSHILwOOD et al. 2001; WADLEY et al. 2009; MAREAN 2010; MAREAN et al. 2010), but the environmental context for this trajectory has not been fully developed, notwithstanding preliminary research (BAR-MATTHEWs et al. 2010; BRUCH et al. 2012). Under the modern climate regime the sites that contain Middle Stone Age (MSA) occupations are distributed between summer rainfall (Rose Cottage Cave, Umhlatazana, Border Cave and Sibudu), winter rainfall (Blombos Cave, Pinnacle Point, Diepkloof Cave) and year-round rainfall (Klasies Main site, Boomplaas) regions. The mechanisms that drive climate in southern Africa often lead to inverse rainfall responses in summer and winter rainfall regions and this has implications for the economic adaptation of peoples in different areas during the MSA. The frequency and duration of droughts (USMAN \& REASON 2004) as well as the longer-term climate band shifts (TYsON 1999) and associated environmental changes would have had a profound influence on where people lived. Localised environmental reconstructions from faunal and botanical remains from the sites are potentially influenced by the selections made by the occupants, while reconstructions from speleothem isotopic analyses may be ambiguous and sedimentary records may be poorly resolved. As a result the environmental context for human behaviour is often interpreted from global-scale climate reconstructions that may not apply across all sites. Complications with such interpretations, particularly with archaeological sites located in the mid-latitudes such as Sibudu, may be due to differences between northern and southern hemisphere records, especially with the timing of major events (JANSEN et al. 2007; HALL \& WoODBORNE 2010). When major global climatic events are synchronous they should manifest in regional and local palaeoenvironmental records. In the case of Sibudu, local environmental changes recorded in proxy evidence (e.g., charcoal isotopes, faunal assemblages and macro-botanical remains) from the site may be linked to global events represented in Antarctic ice cores, marine core isotope records and sea-surface temperature records. This highlights the necessity for accurate dating and age models for palaeoenvironmental records, particularly as one looks further back in time (JANSEN et al. 2007).

Sibudu is an important MSA archaeological site in southern Africa (Fig. 1) because of the excellent preservation in the deep sediments in the rock shelter. The modern climate is characterised by high summer temperatures and precipitation (Min: $23^{\circ} \mathrm{C}$, Max: $33^{\circ} \mathrm{C}, \pm 1000 \mathrm{~mm}$ per annum) and mild winters (Min: $16^{\circ} \mathrm{C}$, Max: $25^{\circ} \mathrm{C}$ ) (HAll 2010; BruCH et al. 2012). Most sediment build-up within the site is derived from anthropological debris (PICKERING 2006; GOLDBERG et al. 2009), and the site contains stratified time-related informally- and formally-named lithic assemblages (WADLEY \& JACOBS 2004, 2006). From oldest to most recent, these assemblages represent pre-Still Bay (layers BS to LBG), Still Bay (layers RGS, RGS2), Howiesons Poort (layers PGS to GR), post-Howiesons Poort (layers $\mathrm{Br}$ under YA2 to BSp), late MSA

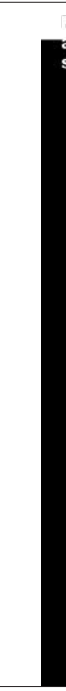

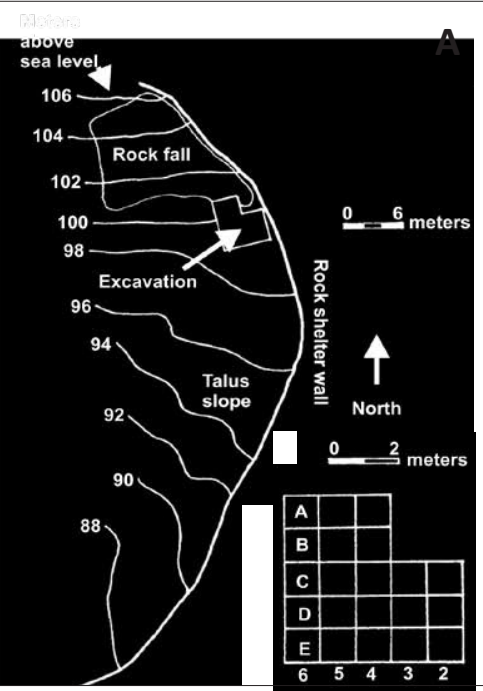

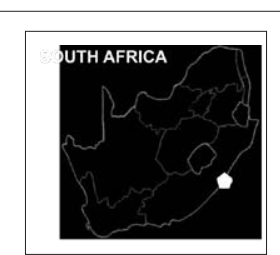

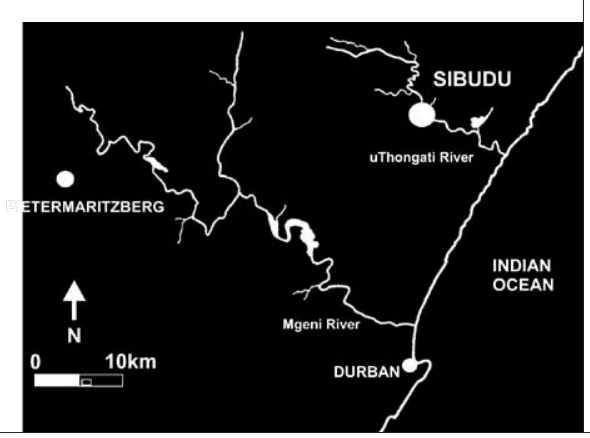

B

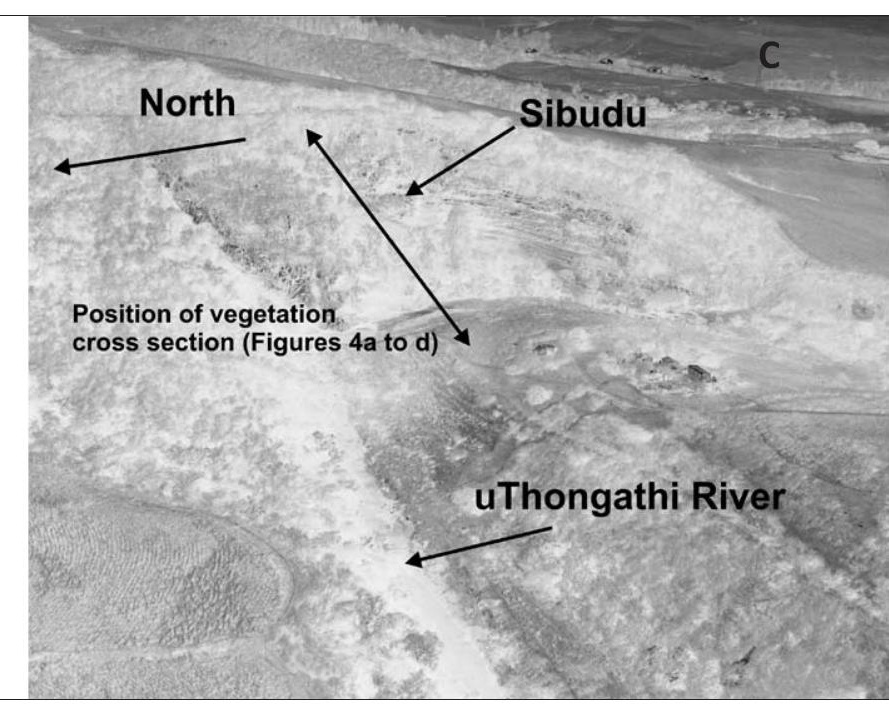

Fig. 1. A: Plan of Sibudu. B: Location of Sibudu. C: Aerial photograph of the Sibudu modern environment showing the location of the shelter, the uThongathi River and orientation of the past vegetation reconstruction transects presented in Fig. 4. The aerial photograph is courtesy of Geoff Nichols. 


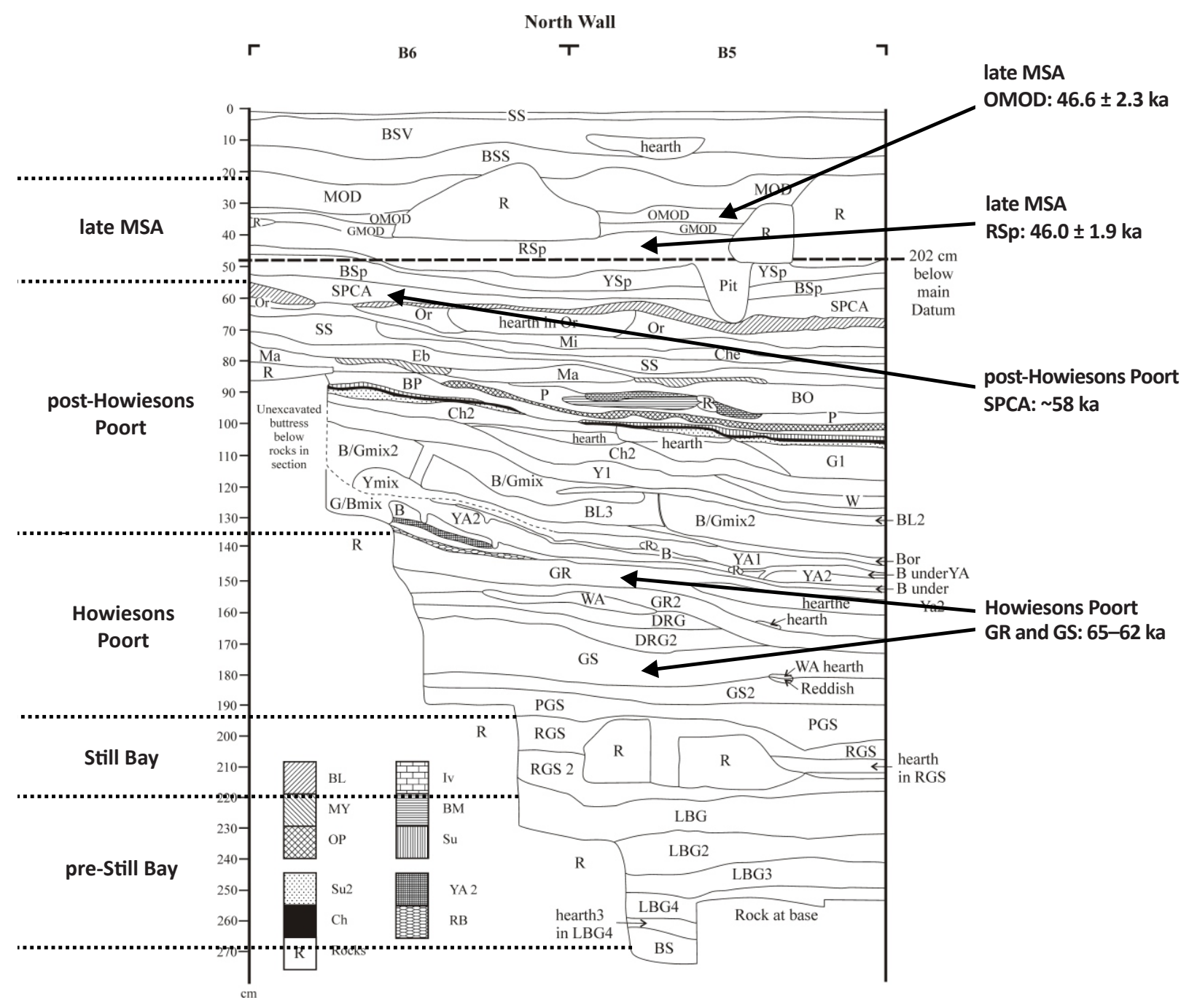

Fig. 2. Stratigraphy of the trial trench in the northern grid at Sibudu. The layers and available ages (JACOBS et al. 2008a, b) from where charcoal samples for this study were collected are indicated.

(layers YSp to PB) and final MSA (layers Mou to Co) (Fig. 2). The pre-Still Bay, post-Howiesons Poort, late MSA and final MSA are informal assemblages that have been preliminarily described (VILLA et al. 2005; COCHRANE 2006; VILLA \& LeNOIR 2006; WADLEY \& JACOBS 2006) and are intended for use only with respect to Sibudu.

The chronology was created using Optically Stimulated Luminescence (OSL) techniques on single quartz grains, yielding 21 ages (JACOBS 2004; WADLEY \& JACOBS 2004, 2006; JACOBS et al. 2008b, b; JACOBS \& RoBERTs 2008). The Howiesons Poort occupation falls between 65-62 ka, the Still Bay dates to $70 \mathrm{ka}$ and the pre-Still Bay to between 77 and $72 \mathrm{ka}$ (JACOBS et al. 2008a; JACOBS \& ROBERTS 2008). There are obvious geological hiatuses of $9.8 \pm 1.3 \mathrm{ka}$ and $12.6 \pm 2.1 \mathrm{ka}$ between the three more recent age clusters, so the site was not continually occupied (WADLEY \& JACOBS 2006;
$\mathrm{J}_{\mathrm{ACOBS}}$ et al. 2008b). Due to the hiatuses it is not possible to provide a continuous sequence of environmental change, but detailed environmental data are available for the occupation pulses.

Multi-disciplinary research has enabled reconstruction of palaeoenvironments for the Howiesons Poort and post-Howiesons Poort, that is, from about 65 to $58 \mathrm{ka} \mathrm{(Tab.} \mathrm{1).} \mathrm{Studies} \mathrm{include:} \mathrm{geomagnetic} \mathrm{sus-}$ ceptibility (HERRIES 2006), mineralogy (SCHIEGL et al. 2004; SCHIEGL \& Conard 2006), geology (Pickering 2006), woody taxa identification from charcoal (ALLOTT 2004, 2005, 2006), carbonised seeds (WADLEY 2004, 2006; Sievers 2006; Sievers \& WAdLey 2008), pollen (RENAUT \& BAMFORD 2006) and macro- and micro-faunal remains (CAIN 2004, 2005, 2006; PLUG 2004, 2006; GlenNy 2006; Wells 2006; Clark \& Plug 2008; WAdLeY et al. 2008). Environmental interpretations based on proxy evidence from archaeo- 


\begin{tabular}{|c|c|c|c|c|c|c|c|c|c|c|}
\hline Layer & Age (ka) & $\begin{array}{l}\text { General environmental } \\
\text { trends }\end{array}$ & Carbon isotopes & Seeds & Charcoal & $\begin{array}{l}\text { Phytoliths \& } \\
\text { Pollen }\end{array}$ & Macrofauna & Microfauna & Mineralogy & Mag Sus. \\
\hline \multicolumn{11}{|c|}{$\begin{array}{l}\text { Occupational hiatus between late and final MSA } \\
\sim 48 \text { ka occupation: late MSA }\end{array}$} \\
\hline $\begin{array}{l}\text { PB } \\
\text { Ore, Ore2 } \\
\text { LBMOD } \\
\text { Cad, Pu }\end{array}$ & $49.9 \pm 2.5$ & & & $\begin{array}{c}\text { Also overall } \\
\text { increase in } \\
\text { deciduous species }\end{array}$ & & & & & $\begin{array}{l}\text { High amounts of } \\
\text { both calcite } \\
\text { and gypsum }\end{array}$ & \\
\hline $\begin{array}{l}\text { MOD } \\
\text { OMOD } \\
\text { OMODBL } \\
\text { OMOD2 } \\
\text { OMODBL } \\
\text { GMOD, BMOD }\end{array}$ & $\begin{array}{l}49.1 \pm 2.5 \\
46.6 \pm 2.3 \\
47.6 \pm 1.9\end{array}$ & $\begin{array}{l}\text { Cooler with more } \\
\text { deciduous taxa }\end{array}$ & $\begin{array}{l}\text { Celtis } \delta^{13} \mathrm{C} \text { values } \\
\text { more negative }\end{array}$ & $\begin{array}{l}\text { Pavetta } \text { and sedge } \\
\text { species present in } \\
\text { most of the layers }\end{array}$ & $\begin{array}{l}\text { Acacia, Erica } \\
\text { charcoal is present } \\
\text { in the upper layers }\end{array}$ & & $\begin{array}{l}\text { Large and medium } \\
\text { sized bovids present }\end{array}$ & & $\begin{array}{l}\text { High amounts of } \\
\text { both calcite } \\
\text { and gypsum }\end{array}$ & $\begin{array}{l}\text { Warmer conditions } \\
\text { indicated. } \\
\text { NOTE: there } \\
\text { is a contradiction } \\
\text { between the Mag sus } \\
\text { and other proxies }\end{array}$ \\
\hline $\begin{array}{l}\text { RSp } \\
\text { YSp }\end{array}$ & $46.0 \pm 1.9$ & $\begin{array}{l}\text { Warming period with } \\
\text { highly mosaic environment }\end{array}$ & $\begin{array}{l}\text { Podocarpus } \delta^{13} \mathrm{C} \text { values } \\
\text { more negative }\end{array}$ & $\begin{array}{l}\text { Phoenix reclinata, } \\
\text { Pavetta sp., sedges }\end{array}$ & $\begin{array}{l}\text { Acacia, Erica, } \\
\text { Podocarpus }\end{array}$ & Grass & $\begin{array}{l}\text { Large and medium } \\
\text { sized bovids present }\end{array}$ & $\begin{array}{l}\text { Mastomys natalensis } \\
\text { indicates succession }\end{array}$ & $\begin{array}{c}\text { Calcite, } \\
\text { high gypsum }\end{array}$ & Warmer \\
\hline \multicolumn{11}{|c|}{$\begin{array}{l}\text { Occupational hiatus between Post-Howiesons Poort and late MSA } \\
\text {-58 ka occupation: Post-Howiesons Poort }\end{array}$} \\
\hline $\begin{array}{l}\text { BSp } \\
\text { BSp2 }\end{array}$ & $57.6 \pm 2.1$ & $\begin{array}{l}\text { Cooler and drier phase } \\
\text { with increased grasslands }\end{array}$ & & $\begin{array}{l}\text { Asparagus sp. } \\
\text { and sedges occur }\end{array}$ & Erica, Acacia, Ficus & & $\begin{array}{l}\text { Large and medium } \\
\text { sized bovids present }\end{array}$ & & High calcite, gypsum & \\
\hline $\begin{array}{l}\text { SPCA } \\
\text { BL, Or }\end{array}$ & & $\begin{array}{l}\text { Warmer conditions with } \\
\text { increased woodlands }\end{array}$ & $\begin{array}{l}\text { Celtis \& Podocarpus } \delta^{13} \mathrm{C} \\
\text { values less negative }\end{array}$ & $\begin{array}{l}\text { Asparagus sp., } \\
\text { Sedges }\end{array}$ & $\begin{array}{l}\text { Erica, Podocarpus, } \\
\text { Leucosidea }\end{array}$ & $\begin{array}{l}\text { Sedge, } \\
\text { Acacia }\end{array}$ & $\begin{array}{l}\text { Large and very } \\
\text { large bovids present }\end{array}$ & & $\begin{array}{l}\text { High calcite, } \\
\text { high gypsum }\end{array}$ & \\
\hline $\begin{array}{l}\mathrm{Mi} \\
\mathrm{SS}\end{array}$ & $59.6 \pm 2.3$ & $\begin{array}{l}\text { Cooler phase, } \\
\text { more grassland }\end{array}$ & & $\begin{array}{c}\text { Seed assemblage } \\
\text { dominated by } \\
\text { evergreen species }\end{array}$ & & Grass & Large bovids & & High gypsum & \\
\hline $\begin{array}{l}\text { Che, Eb } \\
\text { Ma, MY }\end{array}$ & & Warm, dry period & & & $\begin{array}{l}\text { Dry-adapted species } \\
\text { present in assemblage }\end{array}$ & & Large bovids & $\begin{array}{l}\text { Mastomys natalensis } \\
\text { indicates succession }\end{array}$ & Gypsum & Cool \\
\hline $\begin{array}{l}\mathrm{BO} \\
\mathrm{P} \\
\mathrm{OP}\end{array}$ & $59.0 \pm 2.2$ & $\begin{array}{l}\text { Cold phase and } \\
\text { very dry with very } \\
\text { reduced forested areas }\end{array}$ & & Asparagus sp. & $\begin{array}{l}\text { Acacia, Erica, } \\
\text { Ziziphus }\end{array}$ & & Large bovids & & Gypsum & Warm \\
\hline $\begin{array}{l}\text { BP } \\
\text { Iv } \\
\text { BM } \\
\text { Ch } \\
\text { Su, Su2 }\end{array}$ & & $\begin{array}{l}\text { Warming period, cooler } \\
\text { and drier than present }\end{array}$ & & $\begin{array}{l}\text { Asparagus sp., } \\
\text { Podocarpus occur } \\
\text { in the majority of } \\
\text { these layers }\end{array}$ & & $\begin{array}{l}\text { Acacia, Grass, } \\
\text { Fern and } \\
\text { Sedge species }\end{array}$ & $\begin{array}{l}\text { Large bovids } \\
\text { including species } \\
\text { such as buffalo and } \\
\text { equids }\end{array}$ & & $\begin{array}{l}\text { Gypsum in all the } \\
\text { layers, increasing } \\
\text { amounts in lower } \\
\text { layers }\end{array}$ & $\begin{array}{l}\text { A warming trend } \\
\text { is indicated in } \\
\text { these layers }\end{array}$ \\
\hline $\begin{array}{l}\text { G1 } \\
\text { Ch2 } \\
\text { Y1 } \\
\text { B/Mix } \\
\text { BL2, BL3 } \\
\text { Bor, Ymix } \\
\text { YA1 } \\
\text { YA2 } \\
\text { Br under YA2 }\end{array}$ & $\begin{array}{l}58.3 \pm 2.0 \\
58.6 \pm 2.1 \\
58.2 \pm 2.4\end{array}$ & $\begin{array}{l}\text { Coldest period in the MSA } \\
\text { with more open savanna } \\
\text { and grassland environments }\end{array}$ & & $\begin{array}{l}\text { Sedge species } \\
\text { present in all of } \\
\text { these layers }\end{array}$ & & $\begin{array}{l}\text { Grass, Sedge } \\
\text { and Acacia }\end{array}$ & $\begin{array}{l}\text { Large bovids in } \\
\text { all of these layers }\end{array}$ & & $\begin{array}{l}\text { High gypsum in all } \\
\text { the layers, increasing } \\
\text { amounts in lower } \\
\text { layers and also the } \\
\text { presence of calcite }\end{array}$ & $\begin{array}{l}\text { Indications of } \\
\text { cold conditions in } \\
\text { all layers }\end{array}$ \\
\hline \multicolumn{11}{|c|}{$\begin{array}{l}\text { Potential hiatus between Howiesons Poort and Post-Howiesons Poort } \\
65 \text { to } 62 \text { ka occupation: Howiesons Poort }\end{array}$} \\
\hline $\begin{array}{l}\text { GR } \\
\text { GR2 } \\
\text { GS } \\
\text { GS2 } \\
\text { PGS }\end{array}$ & $\begin{array}{l}63.8 \pm 2.5 \\
64.7 \pm 1.9\end{array}$ & $\begin{array}{l}\text { Cold, humid and } \\
\text { moist conditions with } \\
\text { predominance of evergreen } \\
\text { forests dominated } \\
\text { by Podocarpus }\end{array}$ & $\begin{array}{l}\text { Celtis \& Podocarpus } \\
\delta^{13} \text { Calues more negative. } \\
\text { Podocarpus values } \\
\text { have high variability }\end{array}$ & $\begin{array}{l}\text { Sedge species } \\
\text { present in all of } \\
\text { these layers }\end{array}$ & $\begin{array}{l}\text { Podocarpus } \\
\text { dominates the } \\
\text { assemblage and } \\
\text { other forest species } \\
\text { are present }\end{array}$ & & $\begin{array}{c}\text { Small forest } \\
\text { species and lots } \\
\text { of aquatic species. } \\
\text { Blue duiker } \\
\text { dominant small bovid }\end{array}$ & $\begin{array}{l}\text { Presence of Gambian } \\
\text { Giant Rat \& Geoffroy‘s } \\
\text { Horseshoe Bat indicate } \\
\text { presence of forests and } \\
\text { humid conditions }\end{array}$ & $\begin{array}{l}\text { Layers } \\
\text { dominated by } \\
\text { calcite and the } \\
\text { presence of } \\
\text { some gypsum }\end{array}$ & \\
\hline
\end{tabular}

Table 1. Sibudu: summary of proxy environmental evidence. Stratigraphy (Wadley \& Jacobs 2006), ages (Jacobs et al. 2008a, b), formal and informal lithic designation (Wadley \& Jacobs 2006), isotopic data (Hall et al. 2008), botanical (Wadley 2004; Allott 2006; Renaut \& Bamford 2006; Sievers 2006) and faunal data (Plug 2004, 2006; Cain 2006; Glenny 2006; Wells 2006; Clark \& Plug 2008), geology and mineralogy (Schiegl et al. 2004; Pickering 2006; Schiegl \& Conard 2006) and magnetic susceptibility (Herries 2006). 
logical material may be problematic for a number of reasons (WADLEY 2006). These include the introduction of selection bias by natural agents, the original human inhabitants of the site as well as by the site excavators. However, the identification of many sources for the floral, faunal and geological material found at Sibudu provides environmental evidence from a range of localised habitats that would have existed around the site in the past. The degree of material preservation and diagenetic alteration may also influence interpretation. In the case of Sibudu, the interpretation of changing local environmental conditions is strengthened due to a multi-disciplinary combination of high-resolution dating of the site and diverse lines of evidence.

Recently the fossil floral material from Sibudu was subjected to a GIS-based Coexistence Approach $\left(\mathrm{CA}_{\mathrm{GIS}}\right)$ analysis (BRUCH et al. 2012). The $\mathrm{CA}_{\mathrm{GIS}}$ analysis shows that during the Howiesons Poort (HP) Industry winters were slightly colder and drier than present, whereas during summer, temperatures and precipitation were similar to today. The method is based on the assumption that the climate requirements of plant taxa has changed very little since the Neogene and are thus similar to those of their nearest living relatives. Developed by MosBrugger \& UTESCHER (1997), $\mathrm{CA}_{\mathrm{GIS}}$ provides a means of accounting for the fact that natural changes in vegetation may be masked by behavioural changes of the inhabitants of a site. As the method is based on the taxonomic composition of a fossil plant assemblage, all categories of the Sibudu fossil plant assemblage (e.g., seeds, pollen, charcoal and leaves) were combined with twelve climatic and three vegetation parameters to interpret palaeoenvironmental changes in the local vegetation.

Charcoal isotope data is the most recently proposed environmental proxy from the MSA layers of Sibudu and is linked to climate changes in response to sea surface temperatures in the Indian Ocean, shifts in temperate and tropical weather systems and variations in the position, strength and temperature of the Agulhas Current along the south coast (HALL et al. 2008; Hall \& Woodborne 2010; Chase 2010). Although stable carbon isotopic analysis of charred organic matter has been used to track changes in palaeovegetation (e.g., BEHLING \& DA Costa 2001; BeChtel et al. 2002, 2003; BiedENBENDER et al. 2004) and $\delta^{13} \mathrm{C}$ values of archaeological charcoal have been used to track changes in precipitation (FEBRUARY 1992, 1994a, b; FEBRUARY \& VAN DER MERWE 1992; FERrio et al. 2006; Aguilera et al. 2008; Fiorentino et al. 2008; MASI et al. 2013), the success of the approach is dependent on the extent to which the environmental signal in wood is transformed in the charcoal formation process and subsequently during burial. The carbon isotope composition of plant material can change during combustion and the extent of the change depends on the plant organ combusted, its chemical composition, tissue ratios, surface area, the availability of oxygen and the combustion temperature (LEAVITT et al. 1982; CAHIER et al. 1985; BiRD \& GRÖCKE 1997; BALlentine et al. 1998; TUREKIAN et al. 1998; SCHLESER et al. 1999; BALDOCK \& SMERniK 2002; Poole et al. 2002; Krull et al. 2003; STEINBEISS et al. 2006; TURNEY et al. 2006; HAll et al. 2008; BIRD \& AsCOUGH 2012).

HaLl et al. (2008) showed that an environmental signal is preserved in charcoal under constant combustion conditions and that, in the case of Podocarpus, the signal associated with humidity is particularly reliable, but they failed to account for potential post-depositional changes that might have occurred at Sibudu. Although charcoal is considered to be biologically and chemically inert, it undergoes an extremely slow process of degradation and contaminant absorption (e.g., humic and fluvic contaminants) during burial (SKJEMSTAD et al. 1996; BIRD \& GRÖCKE 1997; COHEN-OFRI et al. 2006; Forbes et al. 2006). Diagenetic change to charcoal occurs between sedimentation/burial of the charcoal and subsequent excavation and may include chemical decomposition, microbial degradation and groundwater leaching (STYRING et al. 2013). This diagenetic alteration can result in the biased removal of certain portions of organic matter, the addition of exogenous organic matter (particularly humic acids) and the replacement of endogenous organic matter with exogenous material. These diagenetic alterations may change the isotopic value of the residual organic matter of charcoal samples. In order to account for such potential influences on the carbon isotopic composition of charcoal samples, the agreed method for the pre-treatment of charcoal is the AAA method (Acid-Alkali-Acid) to remove potential contaminants (AsCOUGH et al. 2011a, 2011b; FrASER et al. 2013; StYRING et al. 2013). The $\delta^{13} \mathrm{C}$ values from charcoal may still be considered as a valid method for palaeoclimatic reconstruction provided that appropriate care is taken to account for any post-depositional variation (BIRD \& Ascough 2012).

Here we explore the extent to which post-depositional effects may have affected the isotopic composition of the charcoal. We focus on the charcoal from two tree genera: Podocarpus and Celtis. Podocarpus is considered to be a dominant climax genus in many of the tropical and subtropical forest types in South Africa (Palmer \& Pitman 1972; Acocks 1988; KILlick 1990; SCHMIDT et al. 2002; PoOLEY 2003), and its adaptability to different environmental conditions (which may affect the $\delta^{13} \mathrm{C}$ value) allows the genus to establish and maintain its presence. The 
genus requires high moisture availability and it grows from sea-level to $2150 \mathrm{~m}$. The presence of a Podocarpus community implies a forested environment with effective precipitation, while an absence or limited occurrence of the genus implies reduced forest and drier conditions. Celtis species are more widespread and are adaptable to a larger range of environments than Podocarpus, particularly drier extremes (VAN WYK \& VAN WyK 1997; Acocks 1988; CoATes-PalgraVe 2003; Pooley 2003). We then examine the consistencies between this and other ancient environmental proxies from Sibudu.

\section{Material and methods}

A detailed analysis of the Sibudu charcoal assemblage was carried out by AlLotT $(2004,2005,2006)$. All of Allott's charcoal samples were taken from the initial trial trench which, at the time of sampling, was the deepest part of the excavation. Charcoal was sampled from the sediment matrix and not from distinct hearth features (ALlotT 2006). The archaeological charcoal was identified using a range of documented anatomical features visible under an incident light microscope. These key features were compared with identified charcoal samples from modern reference collections to allow identification to family, genus, species or type (Allott 2006). ALLOTT's (2006) charcoal analysis revealed that a broad range of fuel wood was utilised at Sibudu, but it was not possible to distinguish between wood selection based on choice or environmental availability. The human selection of wood fuel is an important factor (ARCHER 1990), but the local availability of wood is of more important consideration than fuel properties (VAN WyK \& Gericke 2000). This suggests that the Sibudu charcoal assemblage is a good indicator of the temporal components of local woody vegetation surrounding the shelter.

For the purpose of carbon isotope analysis 122 charcoal samples identified as Podocarpus by Allott were obtained from the Grey Rocky (GR) and Grey Sand (GS) layers, both of which occur within the Howiesons Poort (62-65 ka) suite of layers. Seven samples of Celtis charcoal were taken from GS. Twenty samples of Podocarpus comprising P. latifolius and P. falcatus (Allott 2004, 2005, 2006) and 12 samples of Celtis were taken from Spotty Camel (SPCA, $\sim 58 \mathrm{ka}$ ), which is within the post-Howiesons Poort suite of layers. Fifteen samples of Podocarpus were from Red Speckled (RSp) $(46.0 \pm 1.9 \mathrm{ka})$. Thirty-six samples of Celtis were obtained from the Orange Mottled Deposit (OMOD) $(46.6 \pm 2.3 \mathrm{ka})$. These samples are representative of the late MSA suite of layers.
Archaeological charcoal samples were pre-treated with $1 \% \mathrm{HCl}$ overnight and washed with distilled water until $\mathrm{pH}$ neutral. Aliquots of approximately $0.2 \mathrm{mg}$ were combusted on-line in a Flash Elemental Analyser (1112 series) integrated via a Con-flo IV system with a Delta V Plus Isotope Ratio Mass Spectrometer, housed at the Palaeoscience \& Isotope Laboratory, CSIR, Pretoria (all instrumentation supplied by Thermo, Bremen, Germany). Each sample was run in duplicate and if the replicate precision was unacceptable ( $>0.10 \%$ variation), an additional sub-sample was run. The average precision for the replicates of the archaeological samples was $<0.08 \%$ (Hall et al. 2008).

In order to account for the potential effects of post-depositional contaminants, such as humic substances and/or ground water carbonates, subsets of Podocarpus and Celtis charcoal from each period were further pre-treated using the Acid-Alkali-Acid (AAA) method (DE VRIES \& BARENDSEN 1952). The charcoal was treated with a $1 \% \mathrm{HCl}$ solution, washed with distilled water and then treated with a $0.5 \%$ sodium hydroxide $(\mathrm{NaOH})$ solution overnight in a refrigerator, washed with distilled water until $\mathrm{pH}$ neutral and then treated again with a $1 \% \mathrm{HCl}$ solution, washed and dried. These samples were combusted in precisely the same manner as the original samples. The average precision for replicates of the subsets was $<0.09 \%$.

\section{Results}

The $\delta^{13} \mathrm{C}$ values of a particular tree or woody shrub vary according to local site specific factors such as aspect, soil type and proximity to water sources. The isotopic values of Podocarpus reflect a physiological response to the environmental conditions: when water stress increases, isotopic values increase. Where the isotopic values oscillate between high and low values it implies that the tree endured dry and moist environmental conditions. Accordingly, both the absolute value of the isotopes and their variance have environmental implications. A low variance suggests that the trees are using a limited range of their physiological adaptive responses to cope with prevailing environmental conditions, and either the environment shows little temporal variability or the trees existed at the outer limit of their adaptive range.

The mean $\delta^{13} \mathrm{C}$ values for the archaeological charcoal analyses are presented in Figure 3 and summarised in Table 2. The data are composed of the original $\delta^{13} \mathrm{C}$ values presented in HALL et al. (2008) and new $\delta^{13} \mathrm{C}$ values for the archaeological charcoal samples pre-treated by the AAA method. 


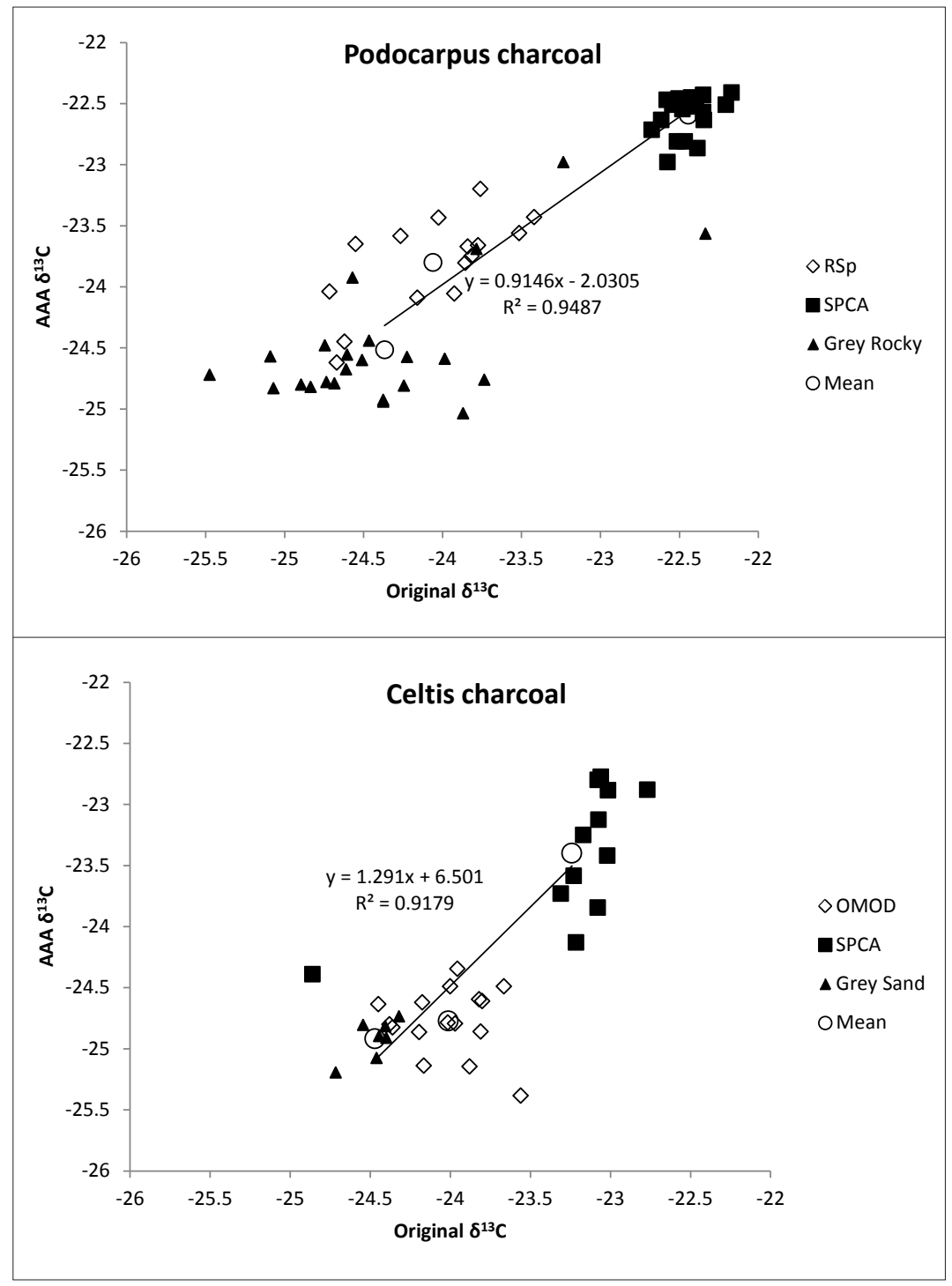

Fig. 3. Original versus AAA treated $\delta^{13} \mathrm{C}$ values for Podocarpus and Celtis archaeological charcoal from Sibudu. A linear trend line and associated equations are provided. The mean $\delta^{13} \mathrm{C}$ values for each layer are displayed as open circles. The sample size from each sample set is large enough to allow meaningful inferences regarding the climatic conditions during each archaeological period.

When the $\delta^{13} \mathrm{C}$ values of the original charcoal samples are compared with their equivalent $\mathrm{AAA} \delta{ }^{13} \mathrm{C}$ values, they suggest that there was relatively little post-depositional contamination of the Sibudu charcoal. The carbon isotope values for the original samples and the AAA samples of both the Podocarpus and Celtis charcoal from all layers were plotted against each other (Fig. 3). A linear trend line shows that there is a 1:1 relationship between the data (Podocarpus $\mathrm{r}^{2}=$ 0.95 and Celtis $\mathrm{r}^{2}=0.92$ respectively), indicating that the isotopic differences between layers are conserved. A Spearmann's Rank Correlation test indicates that the AAA pre-treatment did not significantly alter the carbon isotopic values obtained for each layer $(\mathrm{PO}-$ docarpus $\rho=0.838$, Celtis $\rho=0.718, p<0.5$ for both) and that the environmental interpretation based on the non-AAA treated data is sound.

On average there is $0.2 \%$ difference between the Podocarpus $\delta^{13} \mathrm{C}$ AAA and original values and a $0.5 \%$ difference between the Celtis $\delta^{13} \mathrm{C}$ AAA and original values. The AAA isotopic values for both Podocarpus and Celtis are in general slightly more negative than the original values. The standard deviation, range and variance values from the AAA samples are very similar to those of the original samples (Tab. 2). On the basis of these results, the observed isotopic values of the archaeological charcoal from Sibudu can be considered to reflect an environmental signal, rather than post-depositional contamination. It is important to note that the degree of post-depositional contamination of charcoal must be assessed on a site-by-site basis.

In layer GR (Howiesons Poort) Podocarpus $\delta^{13} \mathrm{C}$ values have a range of $3.14 \%$ and a variance of $0.45 \%$. The wide range of carbon isotope values obtained from Podocarpus charcoal suggests that climate was variable with wet and dry conditions and the trees were not restricted in their adaptive response by prevailing environmental conditions during the 


\begin{tabular}{|c|c|c|c|c|c|c|}
\hline \multirow{5}{*}{$\begin{array}{l}\text { Period } \\
\text { OSL Date }\end{array}$} & \multicolumn{6}{|c|}{ Podocarpus } \\
\hline & \multirow{3}{*}{\multicolumn{2}{|c|}{$\begin{array}{c}\text { RSp } \\
\text { Late MSA } \\
46.0 \pm 1.9 \mathrm{ka}\end{array}$}} & \multirow{3}{*}{\multicolumn{2}{|c|}{$\begin{array}{c}\text { SPCA } \\
\text { Post-Howiesons Poort } \\
\sim 58 \mathrm{ka}\end{array}$}} & \multirow{3}{*}{\multicolumn{2}{|c|}{$\begin{array}{c}\text { Grey Rocky } \\
\text { Howiesons Poort } \\
62-65 \mathrm{ka}\end{array}$}} \\
\hline & & & & & & \\
\hline & & & & & & \\
\hline & Original & $\mathbf{A A A}$ & Original & $\mathbf{A A A}$ & Original & AAA \\
\hline Mean & -24.06 & -23.80 & -22.44 & -22.60 & -24.37 & -24.52 \\
\hline Std dev. & 0.42 & 0.39 & 0.13 & 0.17 & 0.67 & 0.50 \\
\hline Variance & 0.18 & 0.15 & 0.02 & 0.03 & 0.45 & 0.25 \\
\hline Range & 1.30 & 1.42 & 0.50 & 0.57 & 3.14 & 2.06 \\
\hline Minimum & -24.72 & -24.62 & -22.68 & -22.98 & -25.48 & -25.04 \\
\hline Maximum & -23.42 & -23.20 & -22.17 & -22.41 & -22.34 & -22.98 \\
\hline$n$ & 15 & 15 & 20 & 19 & 23 & 23 \\
\hline Correl & & 0.68 & & 0.38 & & 0.61 \\
\hline \multirow[t]{2}{*}{ Covar } & & 0.10 & & 0.01 & & 0.20 \\
\hline & \multicolumn{6}{|c|}{ Celtis } \\
\hline \multirow{4}{*}{$\begin{array}{l}\text { Period } \\
\text { OSL Date }\end{array}$} & \multirow{3}{*}{\multicolumn{2}{|c|}{$\begin{array}{c}\text { OMOD } \\
\text { Late MSA } \\
46.6 \pm 2.3 \mathrm{ka}\end{array}$}} & \multirow{3}{*}{\multicolumn{2}{|c|}{$\begin{array}{c}\text { SPCA } \\
\text { Post-Howiesons Poort } \\
\sim 58 \mathrm{ka}\end{array}$}} & \multirow{3}{*}{\multicolumn{2}{|c|}{$\begin{array}{c}\text { Grey Sand } \\
\text { Howiesons Poort } \\
62-65 \mathrm{ka}\end{array}$}} \\
\hline & & & & & & \\
\hline & & & & & & \\
\hline & Original & $\mathbf{A A A}$ & Original & AAA & Original & AAA \\
\hline Mean & -24.01 & -24.77 & -23.24 & -23.40 & -24.47 & -24.92 \\
\hline Std dev. & 0.26 & 0.27 & 0.53 & 0.54 & 0.13 & 0.16 \\
\hline Variance & 0.07 & 0.07 & 0.28 & 0.29 & 0.02 & 0.03 \\
\hline Range & 0.89 & 1.04 & 2.09 & 1.62 & 0.40 & 0.46 \\
\hline Minimum & -24.45 & -25.39 & -24.86 & -24.39 & -24.72 & -25.20 \\
\hline Maximum & -23.56 & -24.35 & -22.77 & -22.78 & -24.32 & -24.74 \\
\hline$n$ & 16 & 16 & 12 & 12 & 7 & 7 \\
\hline Correl & & 0.68 & & 0.75 & & -0.13 \\
\hline Covar & & 0.18 & & 0.01 & & -0.01 \\
\hline
\end{tabular}

Table 2. Summary statistics for archaeological Podocarpus and Celtis charcoal carbon isotope data from Sibudu. This table incorporates isotope data from Hall et al. (2008) and new values obtained from subsets of charcoal samples that were further treated using the acid-alkali-acid (AAA) method.

Howiesons Poort. In the post-Howiesons Poort SPCA layer Podocarpus $\delta^{13} \mathrm{C}$ values are positive relative to the Howiesons Poort values indicating drier conditions, and they have a narrow range of $0.5 \%$ and the variance is very low $(0.02 \%)$. This suggests that the local distribution of Podocarpus was highly restricted during the post-Howiesons Poort and that it existed at the limit of its adaptive responses to the local environment. In the late MSA (layer RSp) Podocarpus $\delta^{13} \mathrm{C}$ values are again more negative than the post-Howiesons Poort values, with a range of $1.3 \%$ and variance of $0.18 \%$. This suggests wetter conditions than in the SPCA layers and implies that a Podocarpus population utilising a wider range of adaptive responses to local environmental conditions was again established, although the range of responses was not as varied as that seen during the Howiesons Poort.

The mean absolute $\delta^{13} \mathrm{C}$ values for Celtis charcoal from contemporary MSA layers show a similar isotopic distribution pattern to that of Podocarpus. Celtis $\delta^{13} \mathrm{C}$ values are relatively negative during the Howiesons Poort and late MSA and relatively positive during the post-Howiesons Poort (Tab. 2). However, when the range and variance of the Celtis data are considered, these provide low values during the Howiesons Poort compared with those of the Podocarpus samples, suggesting a limited adaptive response to the local environmental conditions. During the post-Howiesons Poort and late MSA the Celtis data have a higher range and variance than Podocarpus. This suggests that both genera could have been affected in different ways by a change in the environment. In dry areas/conditions carbon isotope compositions are affected by relative humidity and soil water status. Under conditions of high moisture availability, sunlight and temperature are responsible for changes in isotopic composition (MCCARROLL \& LOADER 2004). The more positive $\delta^{13} \mathrm{C}$ values for charcoal samples therefore suggest dry, warm conditions during the post-Howiesons Poort to which Celtis is better adapted than Podocarpus. The more negative values seen in the Howiesons Poort are indicative of higher moisture availability and cooler conditions favourable for Podocarpus.

\section{Discussion}

Sibudu is located in a vegetation mosaic that probably persisted throughout the MSA occupations because the aspect of the site and the proximity of the uThongathi River (Fig. 1) affect the range of faunal 
and botanical diversity (WADLEY 2006). The river would have allowed the localised occurrence of certain taxa that would not otherwise have survived in drier areas surrounding the site. The north-eastern slopes and the plateau are more exposed to sunlight than the southern slopes and currently support deciduous woodland, savanna and grassland communities (Fig. 1). The cooler, sheltered south-western cliffs, in which Sibudu is situated, support evergreen forest taxa and would have provided refugia for forest species during drier-than-present periods (Fig. 1). Care is needed when drawing conclusions about changes to climatic and environmental conditions. The anthropogenic origin of the sediments makes the interpretation of proxy environmental evidence, such as geomagnetic susceptibility, more complex. Smallscale oscillations in the magnetic susceptibility curve from Sibudu have been attributed to due amounts of anthropogenically derived material (e.g., from hearths) intermixing (HerRIEs 2006). Large-scale events such as the transition from a cold, dry, glacial phase during MIS 4 to a warmer, moister, interstadial MIS 3 are also reflected in the magnetic susceptibility data (HERries 2006, 2009). However, GoldBERG et al. (2009) point out that the Sibudu sediments are almost entirely anthropogenic and that magnetic susceptibility readings are unlikely to represent climatic change.

Non-isotopic proxy environmental evidence from the site are summarised in Table 1, but some of the interpretations require definitions. Forests comprise predominantly evergreen trees, typically 8 to $30 \mathrm{~m}$ in height, a variety of climbing taxa and epiphytes and low-growing shrubs and ferns on the forest floor, and canopy cover is continuous (RUTHERFORD \& WESTFALL 1986). Savanna is a mixed tropical and subtropical vegetation type comprising predominantly deciduous woody species with a grass component (SCHOLES 1997); it can be divided into sub-types that are dependent on the distribution of woody species. When woody species provide up to $75 \%$ canopy cover, the savanna may be referred to as woodland (RUTHERFORD \& WestFall 1986). Reconstructions of local environment for the Howiesons Poort, post-Howiesons Poort and late MSA periods are summarised below and illustrated in Figure 4.

\section{Howiesons Poort occupations (65-62 ka)}

The occurrence of sedge seeds in all the MSA layers suggests the presence of perennial water in the uThongathi River (SIEvers 2006). Aquatic reptiles and mammals, fresh water molluscs and a variety of waterfowl also attest to a permanent water source close to the shelter (PLUG 2006). A number of evergreen forest taxa have been identified in the charcoal assemblage, including Podocarpus, which is the dominant genus (Allott 2005, 2006). Other taxa such as Kirkia spp. (not present in the area today), which is a dry-adapted genus, were also identified, implying the presence in the vicinity of Sibudu of plant communities requiring drier-than-present conditions. The $\mathrm{CA}_{\mathrm{GIS}}$ analysis of the Howiesons Poort flora suggests that at times during this period of occupation environmental conditions would have been slightly drier and colder than present during winter, but that summer conditions may have been similar to those of today, facilitating the presence of dry-adapted plant communities (BRUCH et al. 2012). The macrobotanical evidence implies a predominantly forested environment, but with neighbouring patches of woodland/savanna (Fig. $4 \boldsymbol{A}$ ) of a kind for which there is no modern analogue.

The botanical evidence is supported by the faunal assemblage. Forest-dwelling mammals such as Cephalophus natalensis (red duiker), Philantomba monticola (blue duiker), Potamochoerus porcus (bushpig), Tragelaphus scriptus (bushbuck) and Chlorocebus aethiops (vervet monkey) are present in the faunal assemblage (CLARK \& Plug 2008). These species are characteristic of modern Podocarpus spp. forest (COOPER 1985), although they may occur in other types of wooded environments. The faunal assemblage at this time mostly comprises $(91.4 \%)$ species inhabiting closed or semi-closed habitats (CLARK \& Plug 2008). Only $8.6 \%$ of species that favour open environments, such as Syncerus caffer (African buffalo), Connochaetes taurinus (blue wildebeest) and Hippotragus equinus (roan antelope) are present in the assemblage. Nonetheless, they imply that there must have been patches of open woodland/savanna and this supports the earlier suggestion that a mosaic of vegetation types probably existed throughout the site occupations. Further evidence for humid, moist, forested environments in the vicinity of the site is provided by the presence of micromammalian species, such as the Gambian giant rat (Cricetomys gambianus) and Geoffroy's horseshoe bat (Rhinolephus clivosus) (SkINNER \& CHIMIMBA 2005; GlenNy 2006). The Gambian giant rat implies cooler-than-present conditions because it cannot tolerate mean summer temperatures above $34^{\circ} \mathrm{C}$. Numerous calcite crystals within the deposits indicate more humid conditions during this time than later in the sequence where gypsum predominates (PICKERING 2006; Schiegl \& Conard 2006; Wadley 2006). Both calcite and gypsum require moisture to form, but gypsum is more soluble in water than calcite and is therefore a better indicator than calcite of locally arid conditions. 

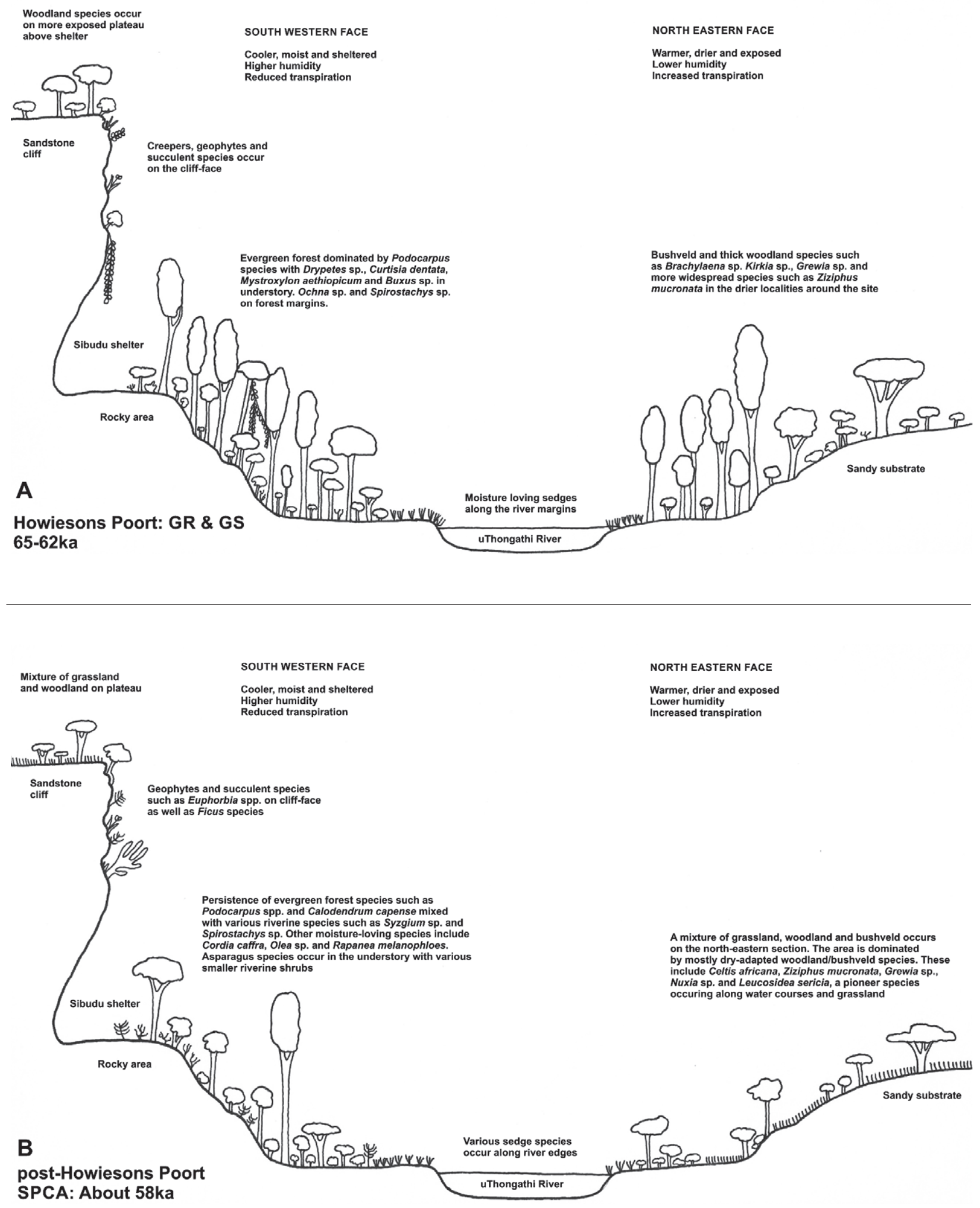

Fig. 4. Schematic reconstruction of (A) the Howiesons Poort (layers GR and GS) vegetation communities and (B) the post-Howiesons Poort (layer SPCA) vegetation communities, based on botanical evidence (WADLEY 2004; ALLOTT 2006; RENAUT \& BAMFORD 2006; SIEVERS 2006). 


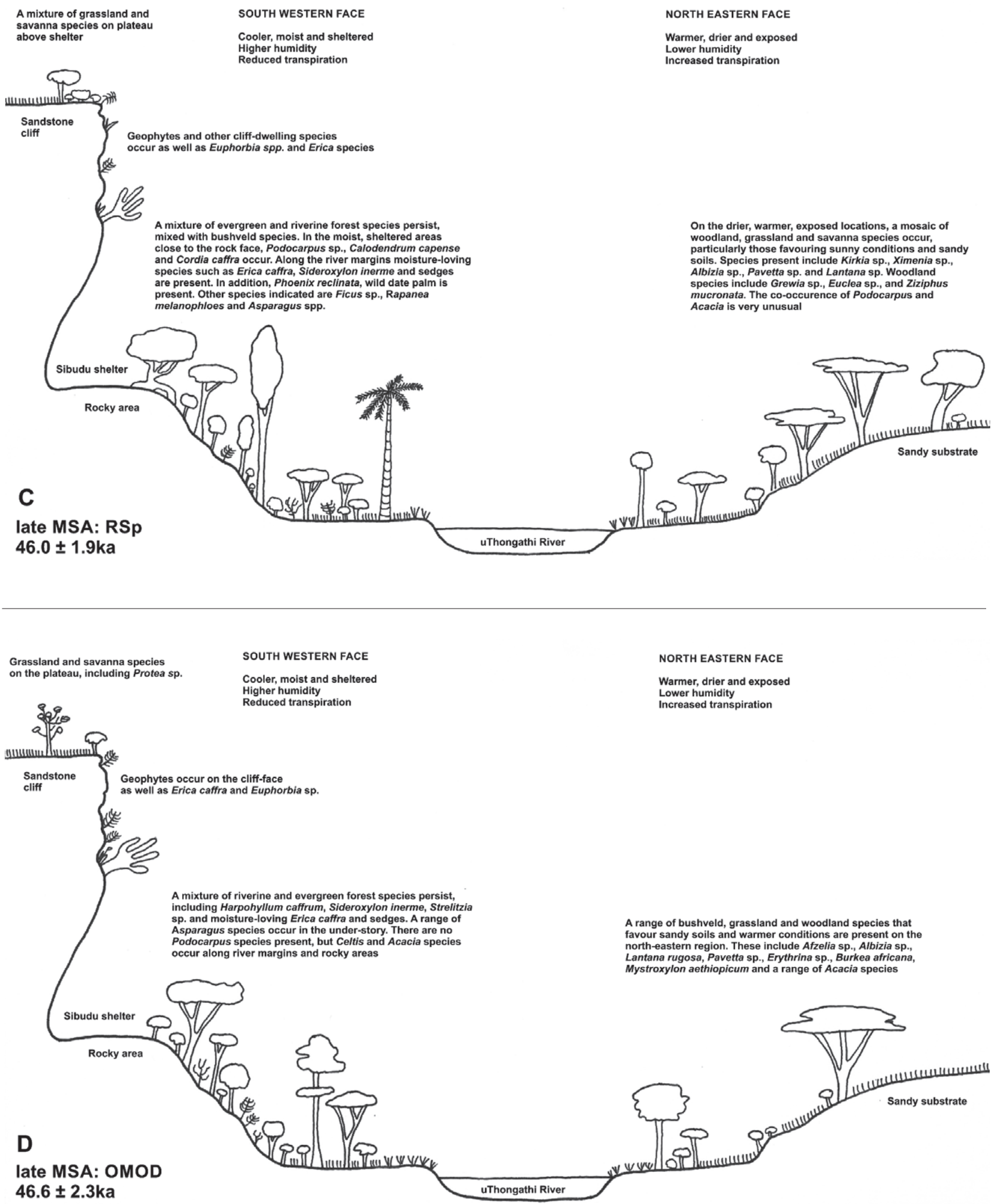

Fig. 4 (continued). Schematic reconstruction of the late MSA vegetation communities from (C) layer RSp, and (D) layer OMOD, based on botanical evidence (WAdLey 2004; Allott 2006; Renaut \& BAMFord 2006; Sievers 2006). 
The proxy evidence from the Howiesons Port layers suggests that the environment around Sibudu Cave was cooler than present. This possibly allowed for more effective moisture retention that supported a substantial evergreen forest, probably on the south-western slopes, with patches of open woodland/savanna within exploitation range of the inhabitants of Sibudu (Fig. 4A). The charcoal $\delta^{13} \mathrm{C}$ values from the Howiesons Poort and late MSA layers fall within the range of modern Podocarpus charcoal values (-28.07\%o to $-23.42 \%$ ) for trees from Seaton Park, KwaZulu-Natal, and this is the nearest available modern analogue.

\section{Post-Howiesons Poort occupations ( 58 ka)}

The changing composition of plant and animal communities in the deep sequence of the post-Howiesons Poort layers provides evidence for oscillating climatic conditions from the coldest period at the end of MIS 4 into MIS 3. Correspondence analysis of the seed and faunal data (REYNOLDS 2006) from this period implies time-related fluctuations in response to a changing environment. Magnetic susceptibility readings imply that the coldest conditions in the Sibudu sequence occurred in the earliest of the post-Howiesons Poort layers (called post-Howiesons Poort MSA 2 by CLARK \& PLUG 2008) at the transition between MIS 4 and MIS 3. $\mathrm{CA}_{\mathrm{GIS}}$ analysis suggests that during this period it was colder and drier than present and summer precipitation was less than today (BRUCH et al. 2012). In more recent layers, magnetic susceptibility results show alternating cooler and warmer conditions with an overall warming trend, although temperatures remained lower than present (HerRIEs 2006). The sediments were largely deposited due to anthropogenic activities within the site (PICKERING 2006; GOLDBERG et al. 2009); therefore the magnetic susceptibility data should be interpreted with care. The lower magnetic susceptibility readings may correlate with periods of reduced human activity rather than a change in the environment, although major climatic events are recorded (HERRIES 2009).

The post-Howiesons Poort seed assemblage comprises a mixture of sedges and woody tree and shrub species (Fig. 4B). Cyperaceae nutlets occurring in the lower layers indicate the presence of open or semipermanent water (SIEVERS 2006). The majority of other identified seeds originate from woody evergreen taxa, but deciduous taxa increase in the upper, more recent layers that coincide with the warming trend. Pollen and phytoliths include representatives of grasses, sedges and fern spores (SchiEgL et al. 2004; RENAUT \& BAmford 2006; Schiegl \& ConARD 2006). The frequency of grass phytoliths increases in the upper layers and this may reflect an increase in grasslands around Sibudu, but this interpretation must be made cautiously because grass could have been used for tinder in some of the fireplaces (SCHIEGL et al. 2004) and also in the plant bedding that was frequently laid on the shelter floor (WADLEY et al. 2011). Woody species from the charcoal assemblage indicate a continuous presence of an evergreen riverine forest component (Allotт 2004, 2005, 2006). Podocarpus reappears in the post-Howiesons Poort layer called SPCA where Acacia species are absent, following the general trend for the two genera to be mutually exclusive (WADLEY 2006). Leucosidea sericea, which can be a pioneer, was identified in the charcoal assemblage of two postHowiesons Poort ( $\sim 58 \mathrm{ka}$ ) layers (Allotт 2006). This species does not occur near to the coast under modern environmental conditions; it occupies high altitudes and is often in areas with cold winters with frost (KILLICK 1990; PoOLEY 2003).

The faunal assemblage of the youngest postHowiesons Poort layers is markedly different in species composition from the earlier Howiesons Poort layers. Small bovid species decrease through the oldest post-Howiesons Poort layers, until they are almost absent in the youngest post-Howiesons Poort layers where large species dominate the assemblage, including equids and large to very large bovids (PLUG 2004; CAIN 2006). Grazers appear throughout, but they are present in higher frequencies in the upper layers (Plug 2004; Cain 2006; Clark \& Plug 2008) suggesting a shift from exploiting fauna in closed forest/ woodland communities to those in drier, more open savanna/grassland communities. The Natal multimammate mouse (Mastomys natalensis), a pioneer species, is found in layer My (GLENNy 2006). Although the species has a wide habitat tolerance, it is not a forest dwelling species and has a degree of water independence, allowing it to occur in dry areas (MEESTER et al. 1979; De GraAfF 1981; SkinNER \& SMithers 1990).

After an initial cold phase during the postHowiesons Poort, a warming trend is observed in the combined proxy evidence. In contrast to the afforestation that existed in the Howiesons Poort, open woodland and grassland communities seem more common by $\sim 58 \mathrm{ka}$. There is an intriguing possibility that the initial post-Howiesons Poort occupations may have taken place during an early phase of succession; this is implied by the presence of the pioneer species Leucosidea sericea (shrub) and Mastomys natalensis (rodent). The charcoal $\delta^{13} \mathrm{C}$ values from the post-Howiesons Poort layer SPCA fall within the range of modern values $(-25.32 \%$ to $-20.07 \%$ ) of a Podocarpus specimen from a refuge forest community from the Baviaans Kloof, Eastern Cape, where Podocarpus is restricted to river margins where there is sufficient moisture availability. 


\section{Late MSA layers ( 48 ka)}

Proxy environmental evidence from the late MSA layers suggests an initial period of warming followed by a cooler period. The occurrence of Cyperaceae nutlets (SIEVERs 2006) and the presence of hippopotamus (Hippopotamus amphibious) (PLUG 2006) attest to the presence of a permanent water source. Seeds from evergreen taxa persist, but the frequencies of deciduous species increase throughout the late MSA sequence (SIEVERS 2006). The $\mathrm{CA}_{\mathrm{GIS}}$ analysis of the flora suggests that the late MSA occupations experienced warmer conditions than the Howiesons Poort and post-Howiesons Poort and that summer precipitation had slightly increased (BRUCH et al. 2012). The charcoal assemblage also reveals an increase in deciduous woody species (Allotт 2006) and the vegetation profile can be interpreted as deciduous savanna woodland with common taxa including Acacia spp., Albizia spp. and Celtis spp. (Fig. 4C and D). In layer RSp (Fig. 4C) there is an unusual combination of Acacia and Podocarpus. This combination of genera is not seen in any other MSA layer at Sibudu (Allott 2006; Wadley 2006). RSp is the youngest Sibudu layer to contain Podocarpus; there is no evidence for its presence in more recent layers (ALLOTT 2006). The phytolith composition at this time shows an overall decrease in grass and an increase in trees (SCHIEGL et al. 2004) suggesting that grassland patches were reduced at the expense of woodland.

The faunal species composition of the late MSA layers suggests a mixed environment. The RSp layer has produced a diverse faunal species profile with savanna, grassland and forest/woodland dwelling species present (Plug 2004; CAIN 2006; Wells 2006). The Gambian giant rat (C. gambianus) is represented again in layer RSp, indicating the presence of forested areas and rainfall over $800 \mathrm{~mm}$ per annum (SKINNER \& Chimimba 2005; Glenny 2006). A substantial environmental change prior to or during the formation of RSp at $46.0 \mathrm{ka}$ is suggested by the re-occurrence of the Natal multimammate mouse (M. natalensis) (GLENNY 2006). Indirect evidence for a climate change between the post-Howiesons Poort and late MSA is also suggested by a hiatus of $9.8 \pm 1.3 \mathrm{ka}$ between these two occupational phases (JACOBS et al. 2008b). Environmental conditions were likely unsuitable for the use of the shelter as a permanent dwelling during the hiatus, perhaps because of a particularly arid phase (JACOBS et al. 2008b). Magnetic susceptibility readings suggest an initial cooling period in OMOD (HERRIES 2006), followed in MOD by a further warming trend.

\section{Interpreting the charcoal isotope data}

Proxy environmental data from Sibudu indicate that environmental conditions during the Howiesons Poort (65-62 ka) were cool and humid favouring the presence of evergreen forests (including Podocarpus) on the southern slopes near the site (Fig. 4A). The mean $\delta^{13} \mathrm{C}$ values for Podocarpus are the most negative $(\mathrm{GR}=-24.62 \%$ and $\mathrm{GS}=-24.47 \%$ o) suggesting that there was relatively high moisture availability at this time. The $\delta^{13} \mathrm{C}$ values have a high sample variance and wide range indicating that the genus was growing in a variety of habitats, for example, close to the river and on the drier hillside. Although Celtis is present contemporaneously, its $\delta^{13} \mathrm{C}$ values have a low sample variance and range, suggesting a limited adaptive response to the shelter talus slope and open, dry north-eastern hillside opposite the shelter.

The $\delta^{13} \mathrm{C}$ values for Podocarpus charcoal from the post-Howiesons Poort ( $\sim 58 \mathrm{ka}$ ) have very low sample variance and range, and they are less negative values than those of the Howiesons Poort sample. The low variance suggests that Podocarpus was exceedingly constrained by the prevailing environmental conditions and was limited in its adaptive responses. The less negative absolute values than before suggest that the genus was responding to more arid conditions. Other factors that may affect carbon isotopic values in trees include relative humidity and soil water states in drier areas and in wetter areas the amount of summer irradiance and temperature (MCCarroll \& Loader 2004). Celtis $\delta^{13} \mathrm{C}$ values from the same period have a higher variance and range than Podocarpus, suggesting that Celtis has a wider distribution and adaptive response to the more arid conditions at about $58 \mathrm{ka}$. Other proxy data from the post-Howiesons Poort imply that forested areas were greatly reduced by the final phase of this long sequence and that conditions were drier and with less moisture availability than during the 65-62 ka Howiesons Poort occupations.

During the late MSA ( 48 ka) occupation represented here by layer RSp, changes in proxy environmental data suggest that a mosaic vegetation occurred around Sibudu, comprising a mixture of grassland, savanna, woodland, evergreen and riverine forest communities (Fig. $4 \boldsymbol{C}$ and $\boldsymbol{D}$ ). The sheltered south-western areas would have favoured evergreen forest species, such as Podocarpus. Stable carbon isotope values of Podocarpus charcoal from the late MSA (RSp layer) show a higher variance and range than those from the post-Howiesons Poort, but much lower than those of the Howiesons Poort charcoal. This suggests that at 
about $\sim 48 \mathrm{ka}$, only certain microhabitats were suitable for Podocarpus. Mean $\delta^{13} \mathrm{C}$ values for Podocarpus and Celtis are more negative again in the late MSA, sug-gesting that available moisture levels were higher than those during the post-Howiesons Poort. No Celtis char-coal was found in layer RSp, but $\delta^{13} \mathrm{C}$ values for Celtis charcoal from layer OMOD (also with an age of $\sim 48 \mathrm{ka}$ ) suggest that the genus was able to establish itself in a similar fashion as seen at $\sim 58 \mathrm{ka}$ (Fig. 4D). The sample variance and range for the OMOD data are similar to those of the SPCA data suggesting that environmental conditions during both periods were suitable for Celtis.

\section{Conclusion}

Stable carbon isotope values from archaeological charcoal samples of two genera, Podocarpus and Celtis, from MSA layers at Sibudu Cave, have provid-ed proxy environmental data that support those from other archaeological sources. The consistencies in the environmental interpretation of the $\delta^{13} \mathrm{C}$ charcoal data and the other palaeoenvironmental proxies from Sibudu Cave through time imply that the patterns in the isotopic data are not an artefact of charcoal forma-tion at different burning temperatures, nor are they an artefact of post-depositional contamination.

The integration of the different environmental proxies from Sibudu suggests that during the Howiesons Poort (65-62 ka) the local environment was thickly forested, moist and more humid than at $\sim 58$ ka. The environment changed during the postHowiesons Poort occupation ( $\sim 58 \mathrm{ka})$ into the late MSA occupa-tion ( $\sim 8 \mathrm{ka})$; it became drier and colder than present with vegetation shifting to open savanna grassland or woodlands.

\section{Acknowledgements}

The following people provided invaluable assistance: Lucy Allott for permission to use her identified char-coal samples from Sibudu Cave for isotopic analy-ses, Lance Rasmussen (Ethekwini Municipality Park Department) for permission to collect samples from Seaton Park, Christine Sievers for assistance in the lo-cation and collection of suitable sample materials, Ge-off Nichols for permission to use the aerial photograph in Figure 1 and Professor Mary Scholes for comments and suggestions to greatly improve the manuscript. Financial assistance for the project is gratefully acknowledged from the Palaeo-Anthropological Scientific Trust (PAST), the National Research Foundation (NRF), the Council for Scientific and Industrial Research (CSIR) and the University of the Witwatersrand. The Palaeoscience and Isotope Laboratory,
CSIR, is to be thanked for the use of its equipment. Opinions expressed here are not necessarily shared by any of the funding agencies or institutions.

\section{References}

Acocks, J.P.H. 1988. Veld Types of South Africa. 3rd. ed. Memoirs of the Botanical Survey South Africa 57. Botanical Research Institute, Pretoria.

Aguilera, M., Espinar, C., Ferrio, J.P., Pérez, G. \& Voltas, J. 2008. A map of autumn precipitation for the third millennium $\mathrm{BP}$ in the eastern Iberian peninsula from charcoal carbon isotopes. Journal of Geochemical Exploration 102, 157165. http://dx.doi.org/10.1016/j.gexplo.2008.11.019

Allott, L.F. 2004. Changing environments in Oxygen Isotope Stage 3: reconstructions using archaeological charcoal from Sibudu Cave. South African Journal of Science 100 (3-4), 179-184.

Allott, L.F. 2005. Palaeoenvironments of the Middle Stone Age at Sibudu Cave, KwaZulu-Natal, South Africa: An Analysis of Archaeological Charcoal. Unpublished Ph.D. Thesis, University of the Witwatersrand, Johannesburg.

Allott, L.F. 2006. Archaeological charcoal as a window on palaeovegetation and wood use during the Middle Stone Age at Sibu-du Cave. Southern African Humanities 18 (1), 173201.

Archer, F. 1990. Planning with people - ethnobotany and African uses of plants in Namaqualand (South Africa). Mitteilungen aus dem Institut för Allgemeine Botanik Hamburg 23 (b), 959-972.

Ascough, P.L., Bird, M.I., Francis, S.M. \& Lebl, T. 2011 a. Alkali extraction of archaeological and geological charcoal: evidence for diagenetic degradation and formation of humic acids. Journal of Archaeological Science 38 (1), 69-78. http://dx.doi.org/10.1016/ j.jas.2010.08.011

Ascough, P.L., Bird, M.I., Francis, S.M., Thornton, B., Midwood, A.J., Scott, A.C. \& Apperley, D. 2011b. Variability in oxidative degradation of charcoal: influence of production conditions and environmental exposure. Geochimica et Cosmochimica Acta 75 (9), 2361-2378. http://dx.doi. org/10.1016/j.gca.2011.02.002

Baldock, J.A. \& Smernik, R.J. 2002. Chemical composition and bioavailability of thermally altered Pinus resinosa (Red pine) wood. Organic Geochemistry 33 (9), 10931109. http://dx.doi.org/10.1016/S0146-6380(02)00062-1

Ballentine, D.C., Macko, S.A. \& Turekian, V.C. 1998. Variability of stable carbon isotopic compositions in individual fatty acids from combustion of $\mathrm{C}_{4}$ and $\mathrm{C}_{3}$ plants: implications for biomass burning. Chemical Geology 152 (1-2), 151-161. http://dx.doi. org/10.1016/S0009-2541(98)00103-X

Bar-Matthews, M., Marean, C., Jacobs, Z., Karkanas, P., Fisher, E.C., Herries, A.I.R., Brown, K., Williams, H.M., Bernatchez, J., Ayalon, A. \& Nilssen, P.J. 2010. A high resolution and continuous isotopic speleothem record of palaeoclimate and palaeoenvi-ronments from 90 to $53 \mathrm{ka}$ from Pinnacle Point on the south coast of South Africa. Quaternary Science Reviews 29 (17-18), 2131-2145. http:// dx.doi.org/10.1016/j.quascirev.2010.05.009 
Bechtel, A., Sachsenhofer, R.F., Gratzer, R., Lücke, A. \& Püttmann, W. 2002. Parameters determining the carbon isotopic composition of coal and fossil wood in the Early Miocene Oberdorf lignite seam (Styrian Basin, Austria). Organic Geochemistry 33 (8), 1001-1024. http:// dx.doi.org/10.1016/S0146-6380(02)00054-2

Bechtel, A., Sachsenhofer, R.F., Markic, M., Gratzer, R., Lücke, A. \& Püttmann, W. 2003. Palaeoenvironmental implications from biomarker and stable isotope investigations on the Pliocene Velenje lignite seam (Slovenia). Organic Geochemistry 34 (9), 1277-1298. http://dx.doi.org/10.1016/ S0146-6380(03)00114-1

Behling, H. \& da Costa, M.L. 2001. Holocene vegetational and coastal environmental changes from the Lago Crispin record in northeastern Pará State, eastern Amazonia. Review of Palaeobotany and Palynology 114 (3-4), 145155. http://dx.doi.org/10.1016/S0034-6667(01)00044-6

Biedenbender, S.H., McClaran, M.P., Quade, J. \& Weltz, M.A. 2004. Landscape patterns of vegetation change indicated by soil carbon isotope composition. Geoderma 119 (1-2), 6983. http://dx.doi.org/10.1016/S0016-7061(03)00234-9

Bird, M.I \& Ascough, P.L. 2012. Isotopes in pyrogenic carbon: a review. Organic Geochemistry 42 (12), 1529-1539. http://dx.doi.org/10.1016/j.orggeochem.2010.09.005

Bird, M.I. \& Gröcke, D.R. 1997. Determination of the abundance and carbon isotope composition of elemental carbon in sediments. Geochimica et Cosmochimica Acta 61 (16), 34133423. http://dx.doi.org/10.1016/S0016-7037(97)00157-9

Bruch, A.A., Sievers, C. \& Wadley, L. 2012. Quantification of climate and vegetation from southern African Middle Stone Age sites - an application using Late Pleistocene plant material from Sibudu, South Africa. Quaternary Science Reviews 45, 7-17. http://dx.doi.org/10.1016/ j.quascirev.2012.04.005

Cahier, H., Buat-Menard, P. \& Fontugne, M. 1985. Source terms and source strengths of the carbonaceous aerosol in the tro-pics. Journal of Atmospheric Chemistry 3 (4), 469-489. http://dx.doi.org/10.1007/BF00053872

Cain, C.R. 2004. Notched, flaked and ground bone artefacts from Middle Stone Age and Iron Age layers of Sibudu Cave, KwaZulu-Natal, South Africa. South African Journal of Sci-ence 100 (3-4), 195-197.

Cain, C.R. 2005. Using burnt bone to look at Middle Stone Age occupation and behaviour. Journal of Archaeological Science 32 (6), 873-884. http://dx.doi.org/10.1016/ j.jas.2005.01.005

Cain, C.R. 2006. Human activity suggested by the taphonomy of $60 \mathrm{ka}$ and $50 \mathrm{ka}$ faunal remains from Sibudu Cave. Southern African Humanities 18 (1), 241-260.

Chase, B.M. 2010. South African palaeoenvironments during marine oxygen isotope stage 4: a context for the Howiesons Poort and Still Bay industries. Journal of Archaeological Science 37 (6), 1359-1366. http://dx.doi.org/10.1016/ j.jas.2009.12.040

Clark, J.L. \& Plug, I. 2008. Animal exploitation strategies during the South African Middle Stone Age: Howiesons Poort and post-Howiesons Poort fauna from Sibudu Cave. Journal of Human Evolution 54 (6), 886-898. http://dx.doi. org/10.1016/j.jhevol.2007.12.004
Coates-Palgrave, K. 2003. Trees of Southern Africa. Struik Publishers, Cape Town.

Cochrane, G.W.G. 2006. An analysis of the lithic artefacts from the $\sim 60$ ka layers of Sibudu Cave. Southern African Huma-nities 18 (1), 69-88.

Cohen-Ofri, I., Weiner, L., Boaretto, E., Mintz, G. \& Weiner, S 2006. Modern and fossil charcoal: aspects of structure and di-agenesis. Journal of Archaeological Science 33 (3), 428439. http://dx.doi.org/10.1016/j.jas.2005.08.008

Cooper, K.H. 1985. The Conservation Status of Indigenous Forests in Transvaal, Natal and Orange Free State, South Africa. Wild-life Society of South Africa, Conservation Division, Durban.

De Graaff, G. 1981. The Rodents of Southern Africa: Notes on Their Identification, Distribution, Ecology and Taxonomy. Butterworths \& Co., Durban.

De Vries, H. \& Barendsen, G.W. 1952. A new technique for the measurement of age by radiocarbon. Physica 18 (8-9), 652. http://dx.doi.org/10.1016/S0031-8914(52)80066-7

February, E. 1992. Archaeological charcoals as indicators of vegetation change and human fuel choice in the late Holocene at Eland's Bay, western Cape Province, South Africa. Journal of Archaeological Science 19 (3), 347-354. http://dx.doi. org/10.1016/0305-4403(92)90021-T

February, E. 1994a. Palaeoenvironmental reconstruction in the Natal Drakensberg using wood charcoal as a conservation management model. South African Journal of Science 90, 549-551.

February, E. 1994b. Rainfall reconstruction using wood charcoal from two archaeological sites in South Africa. Quaternary Research 42;(1), 100-107. http://dx.doi.org/10.1006/ qres.1994.1057

February, E. \& van der Merwe, N.J. 1992. Stable carbon isotope ratios of wood charcoal during the last 4000 years: anthropogenic and climatic influences. South African Journal of Science 88, 291-292.

Ferrio, J.P., Alonso, N., López, J.B., Araus, J.L. \& Voltas, J. 2006. Carbon isotope composition of fossil charcoal reveals aridity changes in the NW Mediterranean Basin. Global Change Biology 12 (7), 1253-1266. http:// dx.doi.org/10.1111/j.1365- 2486.2006.01170.x

Fiorentino, G., Caracuta, V., Calcagnile, L., D’Elia, M., Matthiae, P., Mavelli, F. \& Quarta, G. 2008. Third millennium B.C. climate change in Syria highlighted by carbon stable isotope analysis of ${ }^{14} \mathrm{C}$-AMS dated plant remains from Ebla. Palae-ogeography, Palaeoclimatology, Palaeoecology $266 \quad(1-2), \quad$ 51-58. http:// dx.doi.org/10.1016/j.palaeo.2008.03.034

Forbes, M.S., Raison, R.J. \& Skjemstad, J.O. 2006. Formation, transformation and transport of black carbon (charcoal) in terrestrial and aquatic ecosystems. Science of the Total Environment 370 (1), 190-206. http://dx.doi.org/10.1016/ j.scitotenv.2006.06.007

Fraser, R.A., Bogaard, A., Charles, M., Styring, A.K., Wallace, M., Jones, G., Ditchfield, P. \& Heaton, T.H.E. 2013. Assessing natural variation and the effects of charring, burial and pre-treatment on the stable carbon and nitrogen isotope values of archaeobotanical cereals and pulses. Journal of Archaeological Science 40 (12), 4754-4766. http:// dx.doi.org/10.1016/j.jas.2013.01.032 
Glenny, W. 2006. An analysis of the micromammal assemblage from Sibudu Cave, KwaZulu-Natal. Southern African Huma-nities 18 (1), 279-288.

Goldberg, P., Miller, C.E., Schiegl, S., Ligouis, B., Berna, F., Conard, N.J. \& Wadley, L. 2009. Bedding, hearths, and site maintenance in the Middle Stone Age of Sibudu Cave, KwaZulu-Natal, South Africa. Archaeological and Anthro-pological Sciences 1 (2), 95-122. http:// dx.doi.org/10.1007/s12520-009-0008-1

Hall, G. 2010. Reconstruction of Ancient Environments Using Stable Isotope Analysis of Archaeological Charcoal from Sibudu Cave, KwaZulu-Natal. Unpublished Ph.D. Thesis, University of the Witwatersrand, Johannesburg.

Hall, G. \& Woodborne, S. 2010. Ecosystem change during MIS 4 and early MIS 3: evidence from Middle Stone Age sites in South Africa. In: Runge, J. (ed.), African Palaeoenvironments and Geomorphic Landscape Evolution. Palaeoecology of Africa 30. CRC Press, Boca Raton, pp. 79-106.

Hall, G., Woodborne, S. \& Scholes, M. 2008. Stable carbon isotope ratios from archaeological charcoal as palaeoenvironmental indicators. Chemical Geology 247 (3-4), 384400. http://dx.doi.org/10.1016/j.chemgeo.2007.11.001

Henshilwood, C.S., Sealy, J.C., Yates, R., Cruz-Uribe, K., Goldberg, P., Grine, F.E., Klein, R.G., Poggenpoel, C., van Niekerk, K. \& Watts, I. 2001. Blombos Cave, Southern Cape, South Africa: preliminary report on the 1992-1999 excavations of the Middle Stone Age levels. Journal of Archaeological Science 28 (4), 421-448. http://dx.doi. org/10.1006/jasc.2000.0638

Herries, A.I.R. 2006. Archaeomagnetic evidence for climate change at Sibudu Cave. Southern African Humanities 18 (1), 131-147.

Herries, A.I.R. 2009. New approaches for integrating palaoemagnetic and mineral magnetic methods to answer archaeologi-cal and geological questions on Stone Age sites. In: Fairbairn, A.S., O'Connor, S. \& Marwick, B. (eds.), New Directions in Archaeological Science. Australian National University (ANU) Press, Canberra, pp. 235-253.

Jacobs, Z. 2004. Development of Luminescence Dating Techniques for Dating Middle Stone Age Sites in South Africa. Ph.D. Thesis, University of Wales, Aberystwyth.

Jacobs, Z. \& Roberts, R.G. 2008. Testing times: old and new chronologies in the Howiesons Poort and Still Bay industries in environmental context. South African Archaeological Society Goodwin Series 10, 9-34.

Jacobs, Z., Roberts, R.G., Galbraith, R.F., Deacon, H.J., Grün, R., Mackay, A., Mitchell, P., Vogelsang, R. \& Wadley, L. 2008a. Ages for the Middle Stone Age of southern Africa: implica-tions for human behaviour and dispersal. Science 322 (5902), 733-735. http://dx.doi.org/10.1126/ science. 1162219

Jacobs, Z., Wintle, A., Duller, G.A.T., Roberts, R.G. \& Wadley, L. 2008b. New ages for the post-Howiesons Poort, late and final Middle Stone Age of Sibudu, South Africa. Journal of Archaeological Science 35 (7), 1790-1807. http:// dx.doi. org/10.1016/j.jas.2007.11.028
Jansen, E., Overpeck, J., Briffa, K.R., Duplessy, J.-C., Joos, F., Masson-Delmotte, V., Olago, D., Otto-Bliesner, B., Peltier, W.R., Rahmstorf, S., Ramesh, R., Reynaud, D., Rind, D., Salomina, O., Villalba, R. \& Zheng, D. 2007. Palaeoclimate. In: Solomon, S., Qin, D., Manning, M., Chen, Z., Marquis, M., Averyt, K.B., Tignor, M. \& Miller, H.L. (eds.), Climate Change 2007: The Physical Science Basis. Contribution of Working Group I to the Fourth Assessment Report of the Intergovernmental Panel on Climate Change. Cambridge University Press, Cambridge (UK) and New York (USA), pp. 435-497.

Killick, D. 1990. A Field Guide to the Flora of the Natal Drakensberg. Jonathan Ball and Ad. Donker Publishers, Johannesburg.

Krull, E.S., Skjemstad, J.O., Graetz, D., Grice, K., Dunning, W., Cook, G. \& Parr, J.F. 2003. ${ }^{13}$ C-depleted charcoal from $\mathrm{C}_{4}$ grasses and the role of occluded carbon in phytoliths. Organic Geochemistry 34 (9), 1337-1352. http:// dx.doi.org/10.1016/S0146-6380(03)00100-1

Leavitt, S.W., Donahue, D.J. \& Long, A. 1982. Charcoal production from wood and cellulose: implications to radiocarbon dates and accelerator target production. Radiocarbon 24 (1), 27-35.

Marean, C.W. 2010. Pinnacle Point Cave 13B (Western Cape Province, South Africa) in context: the Cape Floral Kingdom, shellfish, and modern human origins. Journal of Human Evolution 59 (3-4), 425-443. http:// dx.doi.org/10.1016/j. jhevol.2010.07.011

Marean, C.W., Bar-Matthews, M., Fisher, E., Goldberg, P., Herries, A., Karkanas, P., Nilssen, P.J. \& Thompson, E. 2010. The stratigraphy of the Middle Stone Age sediments at Pinnacle Point Cave 13B (Mossel Bay, Western Cape Province, South Africa). Journal of Human Evolution 59 (3-4), 234-255. http://dx.doi.org/10.1016/ j.jhevol.2010.07.007

Masi, A., Sadori, L., Zanchetta, G., Baneschi, I. \& Giardini, M. 2013. Climatic interpretation of carbon isotope content of mid-Holocene archaeological charcoals from eastern Anatolia. Quaternary International 303, 64-72. http://dx.doi. org/10.1016/j.quaint.2012.11.010

McCarroll, D. \& Loader, N. 2004. Stable isotopes in tree rings. Quaternary Science Reviews 23 (7-8), 771-801. http://dx.doi. org/10.1016/j.quascirev.2003.06.017

Meester, J., Lloyd, C.N.V. \& Rowe-Rowe, D.T. 1979. A note on the ecological role of Praomys natalensis. South African Journal of Science 75, 183-184.

Mosbrugger, V.\& Utescher, T. 1997. The coexistence approach a method for quantitative reconstruction of Tertiary terrestrial palaeoclimate data using plant fossils. Palaeogeography, Palaeoclimatology, Palaeoecology 134 (1-4), 61-86. $\quad \mathrm{http}: / / \mathrm{dx}$. doi.org/10.1016/ S0031-0182(96)00154-X

Palmer, E. \& Pitman, N. 1972. Trees of Southern Africa. Volume 1.A.A. Balkema, Cape Town

Pickering, R. 2006. Regional geology, setting and sedimentology of Sibudu Cave. South African Humanities 18 (1), 123-129. 
Plug, I. 2004. Resource exploitation: animal use during the Middle Stone Age at Sibudu Cave, KwaZulu-Natal. South African Journal of Science 100 (3-4), 151-158.

Plug, I. 2006. Aquatic animals and their associates from the Middle Stone Age levels at Sibudu. Southern African Hu-manities 18 (1), 289-299.

Poole, I., Braadbaart, F., Boon, J.J. \& van Bergen, P.F. 2002. Stable carbon isotope changes during artificial charring of propagules. Organic Geochemistry 33 (12), 1675-1681. http://dx.doi.org/10.1016/S0146-6380(02)00173-0

Pooley, E. 2003. The Complete Field Guide to Trees of Natal, Zululand and Transkei. Natal Flora Publications Trust, Natal.

Renaut, R. \& Bamford, M.K. 2006. Results of preliminary palynological analysis at Sibudu Cave. Southern African Humanities 18 (1), 235-240.

Reynolds, S. 2006. Temporal changes in vegetation and mammalian communities during Oxygen Isotope Stage 3 at Sibudu Cave, KwaZulu-Natal. Southern African Humanities 18 (1), 301-314.

Rutherford, M.C. \& Westfall, R.H. 1986. Biomes of Southern Africa - An Objective Categorisation. Memoirs of the Botanical Survey of South Africa 54. Botanical Research Institute, Pretoria.

Schiegl, S. \& Conard, N.J. 2006. The Middle Stone Age sediment at Sibudu: results from FTIR spectroscopy and microscopic analyses. Southern African Humanities 18 (1), 149-172.

Schiegl, S., Stockhammer, P., Scott, C. \& Wadley, L. 2004. A mineralogical and phytoliths study of the Middle Stone Age hearths in Sibudu Cave, KwaZulu-Natal, South Africa. South African Journal of Science 100 (3-4), 185194.

Schleser, G.H., Frielingsdorf, J. \& Blair, A. 1999. Carbon isotope behaviour in wood and cellulose during artificial aging. Che-mical Geology $158 \quad(1-2), \quad 121-130 . \quad \mathrm{http}: / /$ dx.doi.org/10.1016/S0009-2541(99)00024-8

Schmidt, E., Lötter, M. \& McCleland, W. 2002. Trees and Shrubs of Mpumalanga and Kruger National Park. Jacana, Johannesburg.

Scholes, R. 1997. Savanna. In: Cowling, R.M., Richardson, D.M. \& Pierce, S.M. (eds.), Vegetation of Southern Africa. Cambridge University Press, Cambridge, pp. 258277.

Sievers, C. 2006. Seeds from the Middle Stone Age layers at Sibudu Cave. Southern African Humanities 18 (1), 203-222.

Sievers, C. \& Wadley, L. 2008. Going underground: experimental carbonization of fruiting structures under hearths. Journal of Archaeological Science 35 (11), 2909-2917. http:// dx.doi. org/10.1016/j.jas.2008.06.008

Skinner, J.D. \& Chimimba, C.T. 2005. The Mammals of the Southern African Subregion. $3^{\text {rd }}$ edition. Cambridge University Press, Cambridge. http://dx.doi.org/10.1017/ CBO9781107340992

Skinner, J.D. \& Smithers, R.H.N. 1990. The Mammals of the Southern African Subregion. $2^{\text {nd }}$ edition. University of Pre-toria, Pretoria.
Skjemstad, J.O., Clarke, P., Taylor, J.A., Oades, J.M. \& McClure S.G. 1996. The chemistry and nature of protected carbon in soil. Australian Journal of Soil Research 34 (2), 251271. http://dx.doi.org/10.1071/SR9960251

Steinbeiss, S., Schmidt, C.M., Heide, K. \& Gleixner, G. 2006. $\delta^{13} \mathrm{C}$ values of pyrolysis products from cellulose and lignin represent the isotope content of their precursors. Journal of Analytical and Applied Pyrolysis 75 (1), 19-26. http:// dx.doi. org/10.1016/j.jaap.2005.03.009

Styring, A.K., Manning, H., Fraser, R.A., Wallace, M., Jones, G., Charles, M., Heaton, T.H.E., Bogaard, A. \& Evershed, R.P. 2013. The effect of charring and burial on the biochemical composition of cereal grains: investigating the integrity of archaeological plant material. Journal of Archaeological Science 40 (12), 4767-4779. http://dx.doi.org/10.1016/j. jas.2013.03.024

Turekian, V.C., Macko, S., Ballentine, D., Swap, R.J. \& Garstang M. 1998. Causes of bulk carbon and nitrogen isotopic fractionations in the products of vegetation burns: laboratory studies. Chemical Geology 152 (1-2), 181-192. http:/ dx.doi. org/10.1016/S0009-2541(98)00105-3

Turney, C.S.M., Wheeler, D. \& Chivas, A.R. 2006. Carbon isotope fractionation in wood during carbonization. Geochi-mica et Cosmochimica Acta 70 (4), 960-964. http:// dx.doi. org/10.1016/j.gca.2005.10.031

Tyson, P.D. 1999. Atmospheric circulation changes and palaeoclimates of southern Africa. South African Journal of Science 95, 194-201.

Usman, M.T. \& Reason, C.J.C. 2004. Dry spell frequencies and their variability over southern Africa. Climate Research 26 (3), 199-211. http://dx.doi.org/10.3354/cr026199

Van Wyk, B.-E. \& Gericke, N. 2000. People's Plants: A Guide to Useful Plants of Southern Africa. Briza, Pretoria.

Van Wyk, B. \& Van Wyk, P. 1997. Field Guide to Trees of Southern Africa. Struik Publishers (Pty) Ltd, Cape Town.

Villa, P., Delagnes, A. \& Wadley, L. 2005. A late Middle Stone Age artifact assemblage from Sibudu (KwaZulu-Natal): comparisons with the European Middle Palaeolithic. Journal of Archaeological Science 32 (3), 399-422. http:// dx.doi. org/10.1016/j.jas.2004.11.007

Villa, P. \& Lenoir, M. 2006. Hunting weapons of the Middle Stone Age and the Middle Palaeolithic: spear points from Sibudu, Rose Cottage and Bouheben. Southern African Humanities 18 (1), 89-122.

Wadley, L. 2004. Vegetation changes between 61500 and 26 000 years ago: the evidence from seeds in Sibudu Cave, KwaZulu-Natal. South African Journal of Science 100 (3-4), 167-173.

Wadley, L. 2006. Partners in grime: results of multi-disciplinary archaeology at Sibudu Cave. Southern African Humanities 18 (1), 315-341.

Wadley, L. \& Jacobs, Z. 2004. Sibudu Cave, KwaZulu-Natal: background to the excavations of Middle Stone Age and Iron Age occupations. South African Journal of Science $100(3-4), 145-151$ 
Wadley, L. \& Jacobs, Z. 2006. Sibudu Cave: background to the excavations, stratigraphy and dating. Southern African Humanities 18 (1), 1-26.

Wadley, L., Hodgskiss, T. \& Grant, M. 2009. Implications for complex cognition from the hafting of tools with compound adhesives in the Middle Stone Age, South Africa. Proceeding of the National Academy of Science 106 (24), 9590-9594. http://dx.doi.org/10.1073/pnas.0900957106

Wadley, L., Plug, I. \& Clark, J.L. 2008. The contribution of Sibudu fauna to an understanding of KwaZulu-Natal environments at $\sim 58 \mathrm{ka}, \sim 48 \mathrm{ka}$ and $\sim 35 \mathrm{ka}$. In: Badenhorst, S., Mitchell, P. \& Driver, J.C. (eds.), Animals and People: Archaeozoological Papers in Honour of Ina Plug. BAR 1849. Archaeopress, Oxford, pp. 34-45.

Wadley, L., Sievers, C., Bamford, M., Goldberg, P., Berna, F. \& Miller, C. 2011. Middle Stone Age bedding construction and settlement patterns at Sibudu, South Africa. Science 334 (6061), 1388-1391. http://dx.doi.org/10.1126/science. 1213317

Wells, C.R. 2006. A sample integrity analysis of faunal remains from the RSp layer at Sibudu Cave. Southern African Humanities 18 (1), 261-277. 